\title{
COMMENTS
}

\section{Navigating in Uncertain Waters: 2006 Update on the Regulation of Ballast Water Discharge in the United States}

Julie A. Aquino*

TABle of Contents

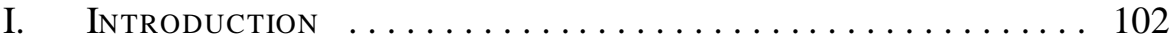

II. Ballast Water Discharge and Invasive Species Generally . . . . . . . . . . . . . . . . . . . . . . . 103

III. Ballast Water Management Methods . . . . . . . . . . . . . . 106

IV. Federal Law . . . . . . . . . . . . . . . . . . . . . . . . 109

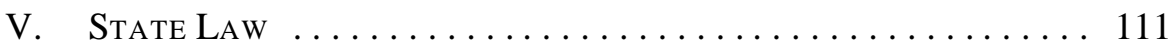

VI. International LaW $\ldots \ldots \ldots \ldots \ldots \ldots \ldots \ldots \ldots \ldots \ldots$

VII. Northwest ENVIRonmental AdVOCATES V. EPA .......... 113

VIII. Weighing the Benefits of Granting the EPA Jurisdiction over BWM Against the Current Coast Guard Regime $\ldots 115$

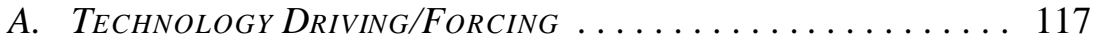

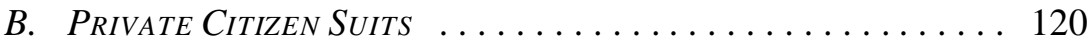

C. The States' Ability to Protect Particular Water Bodies

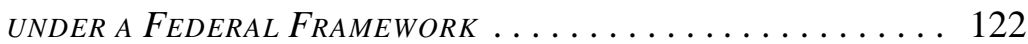

D. AdMINISTRATION AND ENFORCEMENT CHALLENGES . . . . . 123

IX. Conclusion ............................... 124

* Candidate for J.D., University of Pittsburgh School of Law, May 2007. 


\section{INTRODUCTION}

Every day more than 10,000 marine species are swept up in the ballast water of ships and make their way across the globe. ${ }^{1}$ When discharged into non-native waters, these species are able to damage infrastructure, disrupt commerce, out compete native species, reduce biodiversity, and threaten human health. ${ }^{2}$ The ecological losses are difficult to quantify; however, the direct and indirect economic costs have been measured at billions of dollars per year in the United States alone. ${ }^{3}$ Recognizing the severity of the problem, Congress directed the Coast Guard in 1996 to administer a ballast water program and issue guidelines. ${ }^{4}$ According to various interest groups, the aquatic invasive species problem persists today despite Coast Guard involvement because of inherent and technological limitations surrounding ballast water management (BWM). ${ }^{5}$ However, other groups believe that the crux of the problem is that the Coast Guard has simply not acted aggressively enough to address the problem. In March 2005, an environmental advocacy group, joined by six states, convinced a federal district court for the Northern District of California that the EPA had exceeded its statutory authority by exempting the discharge of ballast water from the control of the Clean Water Act (CWA) ${ }^{6}$ in the case of Northwest Environmental Advocates v. EPA. ${ }^{7}$

Uncertainty remains as to whether the EPA will ultimately assume the role of regulating ballast water discharge. Northwest Environmental Advocates is currently awaiting a final remedy order and the EPA is likely to appeal the decision. This Comment will examine the degree to which an EPA

1. National Aquatic Invasive Species Act of 2003: A Bill to Reauthorize the Nonindigenous Aquatic Nuisance Prevention and Control Act: Hearing Before the Subcomm. on Fisheries, Wildlife, and Water, S. Comm. on Env't and Pub. Works, 108th Cong. (2003) (statement of G. Tracey Mehan, Assistant Administrator for Water, U.S. EPA); see also OfFice of Wastewater Management, U.S. EPA OfFice of Water, Aquatic Nuisance Species in Ballast Water Discharges: Issues and Options 4 (Draft Report for Public Comment, 2001) [hereinafter DRAFT REPORT], available at http://www.epa.gov/ npdes/pubs/ballast_report_attch5.pdf.

2. National Aquatic Invasive Species Act of 2005, H.R. 1591, 109th Cong. (2005).

3. $I d$.

4. Eugene H. Buck, Ballast Water Management to Combat Invasive Species, Cong. Res. SERv., RL32344, Mar. 10, 2005, at 4, available at http://www.ncseonline.org/nle/crsreports/05mar/RL32344.pdf.

5. See generally N.W. Envtl. Advocates v. EPA, No. C 03-05760 SI, 2005 U.S. Dist. LEXIS 5373 (N.D. Cal. Mar. 30, 2005)

6. 33 U.S.C. $\$ \S 1251-1387$ (2005).

7. N.W. Envtl. Advocates, 2005 U.S. Dist. LEXIS 5373. 
promulgated BWM program will improve upon the current regime, given that feasible and effective BWM methods remain limited.

Parts II and III of this Comment provide a general overview of the issues related to ballast water discharge and invasive species and various solutions to effective BWM. Parts IV through VI provide a brief summary of federal, state, and international law related to ballast water discharge and invasive species. In Part VII, Northwest Environmental Advocates is discussed. Part VIII provides an examination of the degree to which the invasive species and ballast water problem will be remedied by placing jurisdiction over ballast water discharge with the EPA under the CWA. Part IX concludes that the current regulations promulgated by the Coast Guard are inadequate to effectively manage the invasive species problem and that placing the regulation of ballast water under the CWA would be more likely to result in effective implementation and enforcement of new regulations and innovative solutions to the invasive species problem.

\section{Ballast Water Discharge and Invasive Species Generally}

A ship carrying little weight is vulnerable to instability because it rides high in the water. Therefore, a ship may take on large quantities of the surrounding water located at the start of its voyage. ${ }^{8}$ This water is referred to as ballast water, and is stored in the ship's ballast tanks or cargo holds.' Ballast water enters a ship through intake ports which are typically covered with grates consisting of one-half inch wide openings. ${ }^{10}$ Aquatic species are able to pass through these openings and are drawn into the ship's ballast tanks. ${ }^{11}$ When the ship arrives at a new port these species, along with the ballast water, are frequently discharged into the non-native waters. ${ }^{12}$ The discharge occurs if the ship is loaded with cargo at port and, therefore, no longer needs to carry extra weight for stability. Ballast water can also be carried for other purposes, such as lowering the ship to get under bridges or

8. Andrew N. Cohen \& Brent Foster, The Regulation of Biological Pollution: Preventing Exotic Species Invasions from Ballast Water Discharged into California Coastal Waters, 30 Golden Gate U. L. REv. 787, 790-91 (2000).

9. Id.

10. $I d$.

11. $I d$.

12. Memorandum of Points and Authorities in Support of Plaintiffs' Motion for Summary Judgment at 8, N.W. Envtl. Advocates v. EPA, 2005 U.S. Dist. LEXIS 5373 (N.D. Cal. Mar. 30, 2005) (No. C 03-05760 SI) [hereinafter Plaintiffs' Memorandum]. 
other structures. ${ }^{13}$ Some ships can carry tens of millions of gallons of ballast water, and the EPA acknowledges that over twenty-one billion gallons of ballast water are discharged into the waters of the United States every year. ${ }^{14}$

Seaports in which ships exchange ballast water are at severe risk of harm caused by foreign species. ${ }^{15}$ These species can spread and overwhelm an ecosystem at an alarming rate, causing substantial damage to the ecosystem and the human activities that depend on the ecosystem. ${ }^{16}$ A March 2005 Congressional Research Service report to Congress attributes increases in foreign species' introduction to, among others: increases in the number of people traveling; the speed and methods of travel; and the type and volume of trade. ${ }^{17}$ A 2001 EPA report states that " $[t]$ he volume of water is so enormous, and the transit time that organisms spend[] in ballast water tank[s] is so short, that the number of species successfully invading new habitats via shipping pathway is increasing at an increasingly higher rate." ${ }^{18}$ The EPA also estimates that aquatic invasive species cause over five billion dollars per year in economic damage. ${ }^{19}$

Two of the most affected areas in the United States are the Great Lakes region and the San Francisco Bay ecosystem..$^{20}$ Damage in the Great Lakes area has been incurred by the introduction of the European Zebra mussel, which was discovered in the area in the late 1980s. ${ }^{21}$ The mussel population grew rapidly after the 1980s and clogged water intake pipes of electric utilities and other industries. ${ }^{22}$ In 1996, Congress found that the mussels also infested waters to the south, west, and east of the Great Lakes, and posed a risk to the main waters of the Chesapeake Bay. ${ }^{23}$ Damage estimates have tallied approximately five billion dollars. ${ }^{24}$ Additionally, Zebra mussels have disrupted food webs, promoted blooms of nuisance algae, threatened native species, and accumulated in nuisance quantities on recreational beaches. ${ }^{25}$

3. Cohen \& Foster, supra note 8 , at 791.

14. Id. at 792; DRAFT REPORT, supra note 1 , at 4.

15. Buck, supra note 4, at 2.

16. Plaintiffs' Memorandum, supra note 12, at 4.

17. Buck, supra note 4, at 1.

18. DRAFT REPORT, supra note 1 , at 4.

19. Id. at 9 .

20. Cohen \& Foster, supra note 8, at 793-97.

21. Id. at 796 .

22. Id.

23. 16 U.S.C.S. § 4701(a) (2006).

24. Id.

25. Cohen \& Foster, supra note 8 , at 796. 
Currently, the European Zebra mussel can be found in many areas of the United States beyond the Great Lakes. ${ }^{26}$

The San Francisco Bay ecosystem has been colonized by more than 230 non-native species. ${ }^{27}$ It is believed that fifty-three to eighty-three percent of those species were introduced through ballast water discharge in the last decade. ${ }^{28}$ These non-native species include the Asian clam, the New Zealand sea slug, two or three species of Black Sea jellyfish, over a dozen species of Asian zooplankton, possibly the Chinese mitten crab, and scores of other exotic organisms. ${ }^{29}$ Such non-native species are believed to account for more than "ninety percent of the species, individuals, or biomass in several habitats with in the San Francisco Estuary." ${ }^{30}$ In 2000, the San Francisco Regional Water Quality Control Board concluded that the San Francisco Bay has been significantly degraded by non-native species introduced through ballast water, and that such discharges represent "one of the greatest threats to the San Francisco Estuary ecosystem, perhaps as great as any pollutant under the Clean Water Act." ${ }^{31}$

The speed at which invasive species can dominant an ecosystem is demonstrated by the proliferation of the Asian clam in the San Francisco Bay area. ${ }^{32}$ In 1986, only three specimens of the species were found in the San Francisco Bay. ${ }^{33}$ Within a year, the Asian clam had become the most abundant clam in the northern portion of the Bay. The species eventually spread to the rest of the Bay. ${ }^{34}$ The clam alters the food web of the bay by filtering small organisms out of the water, and concentrating the metal selenium in its tissues, thereby directing selenium into the diets of other animals. $^{35}$

In addition to the species mentioned above, the western Atlantic comb jelly, dinoflagellates, and a South American cholera strain are all examples of invasive organisms introduced in the United States through ballast water

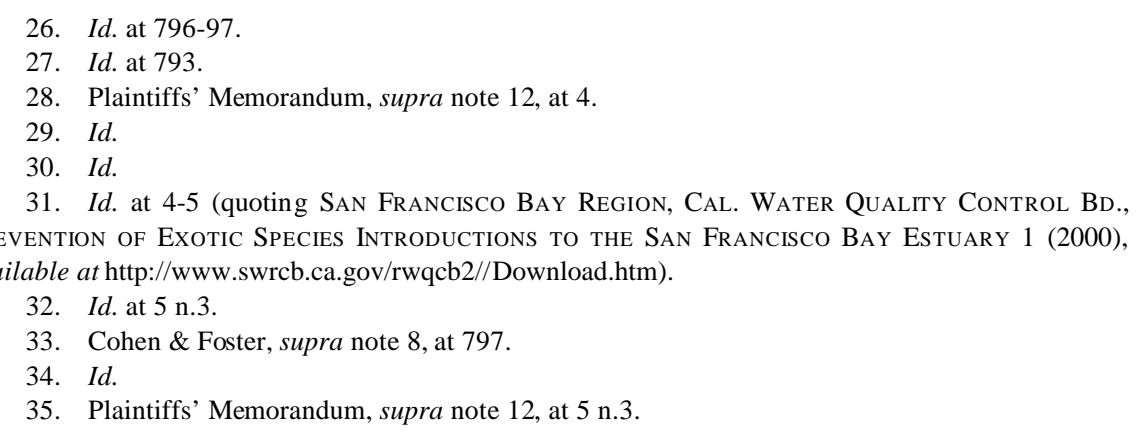


discharge. ${ }^{36}$ In 1991, the South American cholera strain was discovered in oysters and fish in Mobile, Alabama. ${ }^{37}$ The same strain was later found by the U.S. Food and Drug Administration in ships sampled on arrival in the Gulf of Mexico from South American ports. ${ }^{38}$ Some medical researchers believe that this strain of cholera originally had been carried from Asia to South America in ballast water. ${ }^{39}$

Dinoflagellates are microscopic organisms that color the sea when they become very abundant. This coloration of the sea is termed a "red tide." 40 Dinoflagellates are capable of killing both invertebrates and fish and some dinoflagellates produce neurotoxins which can be fatal to humans when consumed in mussels or clams. ${ }^{41}$ Red tides have been reported more frequently around the world in recent decades and in "areas where they were previously unknown." ${ }^{\prime 2}$ Dinoflagellates are common in ballast water and some outbreaks outside of the United States have been attributed to ballast water discharges. ${ }^{43}$

\section{Ballast Water Management Methods}

Although no single management method is deemed to be completely effective due to feasibility and intrinsic limitations, various methods of managing ballast water do exist. ${ }^{44}$ The most widely used method of ballast water management (BWM) is ballast water exchange. ${ }^{45}$ Ballast water exchange means that a ship on its way to the next port releases the lower salinity coastal water it brought aboard and replaces it with higher salinity open ocean water. ${ }^{46}$ The exchange is usually performed at least 200 miles from offshore and is therefore often called "open ocean exchange." ${ }^{47}$

Ballast water exchange is effective because organisms from the open ocean are unlikely to survive or thrive in the lower salinity near shore waters

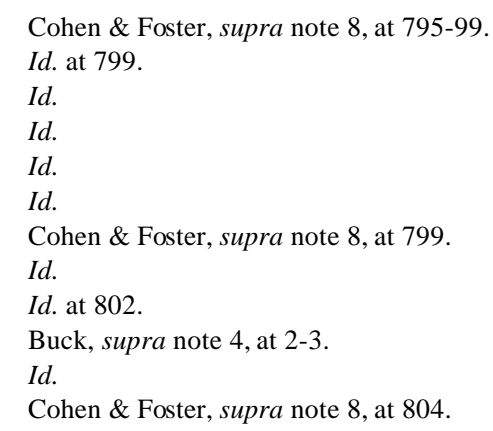


of the ship's next port. ${ }^{48}$ For several reasons, however, ballast water exchange is not a completely effective management solution. Tobegin, organisms with a high tolerance for differing salinity levels may survive ballast water exchange. ${ }^{49}$ Secondly, some organisms picked up at the beginning of the ship's voyage may remain in the unpumpable residual water and in the sediment of the ballast tank during the open ocean exchange and survive when released in the waters of the destination port. ${ }^{50}$ Thirdly, ships engaging strictly in coastal traffic are unlikely to enter waters 200 miles from shore and therefore are unable to perform the exchange. ${ }^{51}$ Finally, due to stability concerns and other potential problems, a rather large exception for the safety of the ship is deemed necessary for any open ocean exchange requirement. ${ }^{52}$ For these reasons, ballast water exchange does not create a completely effective management solution.

The treatment of ballast water is a second approach to BWM and has been the subject of extensive research and development initiatives. ${ }^{53}$ Proposed treatment methods include mechanical methods (filtration and separation), physical methods (sterilization and ultra violet light treatment), and chemical methods (biocide utilization). ${ }^{54}$ These technologies could potentially be applied either onboard ship or in onshore facilities. ${ }^{55}$ The treatment method favored by many ship operators is the use of biocides because of their simplicity and relatively low costs. ${ }^{56}$ The cost of retrofitting vessels to treat ballast water is estimated between $\$ 200,000$ and $\$ 310,000$ per vessel for mechanical treatment and around $\$ 300,000$ for chemical treatment. ${ }^{57}$ Most of this expense will be incurred by foreign shipping companies, as the U.S. fleet

48. Id. at 805 .

49. Buck, supra note 4 , at 3 .

50. Id.; see also DRAFT REPORT, supra note 1, at 10 (noting that "mid-ocean exchange has been only moderately effective" and that even a " 95 percent exchange of the original water resulted in flushing of only 25 to 90 percent of the organisms studied").

51. Cohen \& Foster, supra note 8, at 806.

52. Ballast water exchange can be conducted by an "empty-and-refill exchange" or by "flow-through exchange." The former method presents stability problems, especially for smaller vessels. The latter approach does not present stability concerns, but raises other safety and efficiency issues. Id. at 807-08.

53. Buck, supra note 4 , at 2 .

54. Id.

55. Cohen \& Foster, supra note 8 , at 814-15.

56. Buck, supra note 4 , at 3 .

57. Id. at 3-4. 
is a small percentage of the global fleet. ${ }^{58}$ Consumers of products imported by ship will also bear the costs. ${ }^{59}$

Treatment may be an effective management option particularly for ships which arrive at port with "no ballast on board" (NBOB). ${ }^{60}$ NBOB means that the ship is not carrying significant quantities of ballast water in its holding tanks when it arrives at port. These ships generally have not been required to perform an open ocean exchange; however, a large number of organisms can reside in umpumpable residual water and in the sediment remaining in the empty ballast tanks. ${ }^{61}$ Treatment of this residual water and sediment presents itself as one method to solve the NBOB problem. ${ }^{62}$

The above-mentioned treatment methods are undergoing further study; however, large environmental concerns remain about the disposal of biocide treated water. ${ }^{63}$ Despite these concerns, the treatment of ballast water is thought to be the management method necessary to develop in order to properly address the aquatic invasive species problem.

A third method for minimizing the introduction of invasive species is the "micromanagement" of when or how ballast water is loaded or discharged ${ }^{64}$ Measures related to the loading of ballast include, among others, not loading in areas that are known to contain harmful organisms, not loading in areas with local outbreaks of infectious waterborne diseases, and not loading in areas with high sediment loads. ${ }^{65}$ Other measures include: not ballasting at seasons when harmful plankton are plentiful; not ballasting at night when many types of organisms move closer to the surface; not loading fresh water as ballast when expecting to de-ballast in salt water; and not loading salt water as ballast when expecting to de-ballast in fresh water. ${ }^{66}$ Measures related to the discharge of ballast include not discharging in sensitive regions such as marine sanctuaries and seafood harvesting areas. ${ }^{67}$ Limitations are inherent with the use of "micromanagement," because it only covers particular

58. Id. at 4 .

59. Id.

60. Id. at 3 .

61. Brief for the States of New York, Illinois, Michigan., Minnesota, Wisconsin, and the Commonwealth of Pennsylvania on Selection of Remedy and Final Order of Judgment at 4, N.W. Envtl. Advocates v. EPA, 2005 U.S. Dist. LEXIS 5373 (N.D. Cal. Mar. 30, 2005) (No. C 03-05760 SI).

62. $I d$.

63. Id.

64. Cohen \& Foster, supra note 8, at 801-02.

65. Id. at 802-03.

66. Id.

67. Id. at 803 . 
instances of discharge. However, ballast water "micromanagement" may be effective when used in conjunction with additional BWM methods.

\section{Federal Law}

The Clean Water Act (CWA) ${ }^{68}$ prohibits the "discharge of any pollutant" from a "point source" into navigable waters of the United States without a permit issued under section 402 or 404 of the CWA. ${ }^{69}$ Section 402 establishes the National Pollutant Discharge Elimination System (NPDES) permitting scheme for discharges of pollutants. ${ }^{70}$ The term "pollutant" includes "biological materials," and the term "point source" includes a "vessel or other floating craft." 71 A broad definition applies to "navigable waters," which includes rivers, lakes, estuaries, as well as ocean waters extending out to three miles from shore. ${ }^{72}$ The EPA has primary authority to implement and enforce the CWA. ${ }^{73}$ The EPA establishes the minimum requirements that must apply to all entities that fall under the CWA and states may choose to adopt more stringent standards. ${ }^{74}$

Because the definition of "pollutant" under the CWA includes "biological material," it would appear that ballast water discharge must be regulated under the NPDES permitting system. However, in 1973 the EPA promulgated 40 C.F.R. § 122.3(a), which exempted discharges "incidental to the normal operation of a vessel" from the NPDES permitting requirements. ${ }^{75}$ The EPA has relied upon section 122.3(a) in order to exempt ballast water discharge from the NPDES permitting requirements. However, in the many years since the EPA created the vessel discharge exemption, national and international concerns have come to light regarding the adverse ecological and economic impact caused by aquatic invasive species. Nonetheless, the EPA has continued to rely on this regulation to exemptballast water discharge from the NPDES requirements.

68. 33 U.S.C. $\S 1251-1387$ (2005).

69. See id. $\S 1311(\mathrm{a})$.

70. Id. $\$ 1342$.

71. Id. § 1362(6), (14).

72. Id. § 1362 (7); Cohen \& Foster, supra note 8, at 837-38.

73. 33 U.S.C. $\$ 1251(\mathrm{~d})(2005)$.

74. Plaintiffs' Motion for Permanent Injunctive Relief and Entry of Final Judgment at 7, N.W. Envtl. Advocates v. EPA, 2005 U.S. Dist. Lexis 5373 (N.D. Cal. Mar. 30, 2005) (No. C 03-05760 SI); see also 33 U.S.C. § 1342(b) (2005), 40 C.F.R. § 123.1(i)(1) (2005).

75. 40 C.F.R. $\S 122.3(\mathrm{a})(2005)$. 
Congress attempted to address the growing invasive species concerns with the Nonindigenous Aquatic Nuisance Prevention and Control Act of 1990 (NANPCA). ${ }^{76}$ NANPCA established a federal program to prevent the introduction of aquatic nuisance species. The U.S. Coast Guard, EPA, U.S. Fish and Wildlife Service, Army Corps of Engineers, and National Oceanic and Atmospheric Administration shared responsibilities for implementing NANPCA. ${ }^{77}$ Responsibilities included identifying areas where ballast water exchange can take place without causing environmental damage and determining the need for controls on vessels. ${ }^{78}$ NANPCA also directed the Coast Guard to issue regulations pertaining to the Great Lakes, which were required to become mandatory in 1992. In response, the Coast Guard promulgated 33 C.F.R. pt. 151. This regulation provided that all ships entering the Great Lakes, after operating more than 200 miles from the territorial sea of the United States, perform mid ocean ballast exchange or alternative measures pre-approved by the Coast Guard. ${ }^{79}$ The BWM program also imposed reporting requirements on vessels entering the Great Lakes. ${ }^{80}$

In 1996, NANPCA was amended by the National Invasive Species Act (NISA) ${ }^{81}$ NISA directed the Coast Guard to devise a national BWM program modeled after the Great Lakes program. ${ }^{82}$ This BWM program was not initially mandatory. The program was only to become mandatory within three years of the date the Coast Guard issued its voluntary guidelines, if adequate compliance with the voluntary guidelines was not achieved. ${ }^{83}$ The National Ballast Information Clearinghouse (NBIC) was also developed to analyze data concerning BWM. ${ }^{84}$ The NBIC found that nationwide compliance with voluntary reporting guidelines was as low as $30.4 \%$ within the first two years (July 1999 through June 2001). ${ }^{85}$

Due to inadequate vessel compliance with the voluntary guidelines, the Coast Guard acted to make the guidelines mandatory in 2002. ${ }^{86}$ However, the

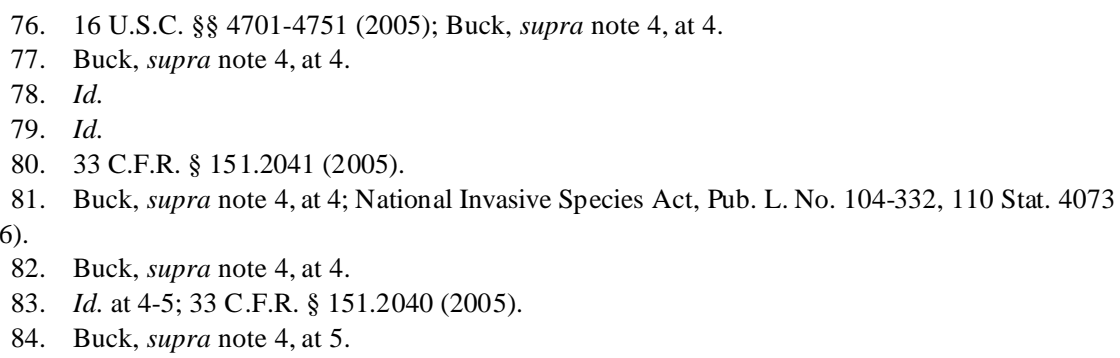


guidelines did not become mandatory until September 2004 because the Coast Guard followed public notice and comment procedures before promulgating the mandatory guidelines. ${ }^{87}$ The 2004 mandatory requirements were codified in 33 C.F.R. pt. $151 .^{88}$

The current mandatory regulations consist of three requirements. First, any vessel equipped with ballast water tanks must file a report with the Coast Guard twenty-four hours prior to arrival at a United States port or place (including inland ports). ${ }^{89}$ The report must include information on the vessel's BWM. Second, all vessels equipped with ballast water tanks must have a vessel-specific water management plan. ${ }^{90}$ Third, all vessels equipped with ballast water tanks entering U.S. waters after operating beyond 200 miles from the territorial sea of the United States must use one of three BWM practices: 1) perform a complete ballast water exchange in an area no less than 200 nautical miles from shore; 2) retain ballast water onboard the vessel; or 3) use an alternative environmentally sound method of BWM that has been approved by the Coast Guard. ${ }^{91}$

\section{State Law}

Due to alleged deficiencies in the federal program, states such as California, Maryland, Oregon, and Washington chose to regulate aspects of BWM. $^{92}$ Although this Comment does not attempt to address federal constitutional questions, it is important to mention that state regulations raise federal preemption and dormant clause issues. ${ }^{93}$ In addressing the federal constitutional concerns, it is worth pointing out that both the language of NISA and the CWA express intent for states to be involved in ballast water

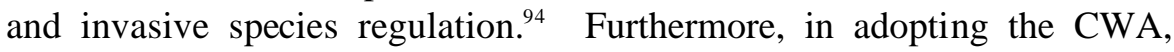
Congress "clearly intended that it serve only as a floor for water quality

87. $I d$.

88. Motion and Supporting Memorandum on Selection of Remedy and to Stay Injunction for The Shipping Industry Ballast Water Coalition at 8-9, N.W. Envtl. Advocates v. EPA, 2005 U.S. Dist. LEXIS 5373 (N.D. Cal. Mar. 30, 2005) (No. C 03-05760 SI).

89. Id.; 33 C.F.R. $\$ 151.2041$ (2005).

90. Id.; 33 C.F.R. $§ 151.2035(\mathrm{a})(7)$.

91. 33 C.F.R. $\$ 151.2035$ (b).

92. Motion and Supporting Memorandum on Selection of Remedy to Stay Injunction for The Shipping Industry Ballast Water Coalition, supra note 88, at 16-19.

93. For an analysis on the constitutional limitations placed on state regulation of ballast water discharge see Cohen \& Foster, supra note 8, at 832-36 (stating that neither the dormant commerce clause nor the Supremacy Clause appear to provide an absolute bar to state regulation of ballast water).

94. Cohen \& Foster, supra note 8, at 834-35. 
protection and that states retain the right to require a greater level of protection." 95

\section{INTERNATIONAL LAW}

International concerns over ballast water discharge were first addressed in 1973 with the United Nations Conference on Marine Pollution. ${ }^{96}$ The conference requested the World Health Organization to investigate the possible spread of epidemic disease in ballast water. ${ }^{97}$

The next international effort took place between 1989 and 1993, when Canada, Australia, New Zealand and the United Nations' International Maritime Organization (IMO) adopted guidelines on BWM. This effort was largely galvanized by concerns over toxic dinoflagellates based on studies of their introduction into Australia via ballast water discharge. ${ }^{98}$ The IMO's member states were asked to follow the guidelines which included open ocean exchange. ${ }^{99}$ A review conducted by Australia in 1993 revealed that few countries had implemented the guidelines. ${ }^{100}$

In 1994, the IMO's Marine Environmental Protection Committee (MEPC) established a working group to draft regulations for the control and management of ballast water. ${ }^{101}$ The IMO later proposed these management protocols as a formal IMO instrument. ${ }^{102}$ This instrument requires all ratifying member nations to follow the regulations which include open ocean exchange. ${ }^{103}$

On February 13, 2004, a convention was adopted at the International Conference on Ballast Water Management for Ships. ${ }^{104}$ Although not yet in effect, the United States was one of the major proponents of this convention which will require all ships to implement a Ballast Water and Sediments Management Plan. ${ }^{105}$ The convention is currently being reviewed by the United States and other countries and will be effective twelve months after

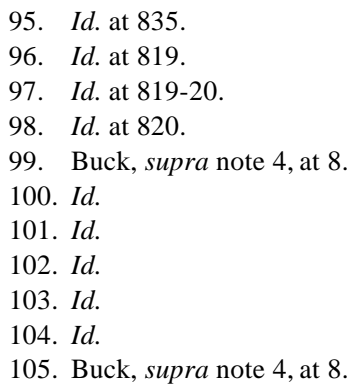


ratification by thirty nations, representing thirty-five percent of the world's merchant shipping tonnage. ${ }^{106}$ A 2005 Congressional Research Service Report states that the likelihood of compliance by the foreign flag fleet with proposed ballast water treatment methods was increased by the February 2004 Conference. ${ }^{107}$

The United States, bilaterally with Canada, is also addressing ballast water concerns by working with the North American Commission for Environmental Cooperation, the Great Lakes Commission, and the International Joint Commission. ${ }^{108}$ It is important to note that many vessel owners would prefer international standards as opposed to the "increasing number of national ballast water programs developed around different approaches for addressing [the] concern." 109

\section{NORTHWEST ENVIRONMENTAL ADVOCATES V. EPA}

On January 13, 1999, an environmental advocacy group, the Northwest Environmental Advocates (NEA), petitioned the EPA to repeal the regulation, 40 C.F.R. § 122.3(a), which exempts discharges "incidental to the normal operation of a vessel" from the NPDES permitting requirements. ${ }^{110}$ Plaintiffs asserted in their petition that the exemption was inconsistent with the plain language of the CWA. ${ }^{111}$ The EPA did not initially respond to the petition. Thereafter, the NEA filed a lawsuit against the EPA, seeking a response to the petition. In 2003, the EPA formally denied the NEA's petition. ${ }^{12}$ The NEA proceeded to file a lawsuit against the EPA in the federal district court for the Northern District of California. The suit, Northwest Environmental Advocates v. $E P A,{ }^{113}$ sought to have the court declare that the EPA exceeded its statutory authority under the CWA by categorically exempting discharges incidental to the normal operation of a vessel from the NPDES permitting requirements. ${ }^{114}$

106. $I d$.

107. Id. at 4 .

108. Id. at 9 .

109. Id. at 8 .

110. Plaintiffs' Motion for Permanent Injunctive Relief and Entry of Final Judgment, supra note 74, at 4 .

111. $I d$.

112. $I d$.

113. N.W. Envtl. Advocates v. EPA, No. C 03-05760 SI, 2005 U.S. Dist. LEXIS 5373 (N.D. Cal. Mar. 30, 2005).

114. N.W. Envtl. Advocates, 2005 U.S. Dist. Lexis 5373, at*6-7. 
The states of Illinois, Michigan, Minnesota, New York, Pennsylvania, and Wisconsin, all of which border on a Great Lake, intervened as plaintiffs.

The plaintiffs argued that because Congress clearly expressed its intent that the discharge of "biological material" be regulated under the NPDES permit system, the EPA's exemption for all discharges "incidental to the normal operation of a vessel" was inconsistent with the plain language of the CWA. ${ }^{115}$ Plaintiffs asserted that, under Chevron U.S.A., Inc. v. National Resources Defense Council ${ }^{116}$ the EPA exceeded its statutory authority and must repeal the exemption. ${ }^{117}$ The EPA did not contest this interpretation of the CWA. Instead the EPA argued that Congress had acquiesced to the EPA's interpretation that discharges incidental to the normal operation of a vessel are exempt from the NPDES regime and therefore the regulation should be upheld. ${ }^{118}$ The EPA attempted to show congressional acquiescence through Congress's failure to repeal the EPA exception in the thirty years of the exception's existence and through Congress's enactment of other legislation to address ballast water management; namely, NANPCA and NISA. ${ }^{119}$

The district court concluded that neither Congress's action, nor its inaction, performs the "difficult task [of] overcoming the plain text and import of the CWA." 120 Because the plain text of the CWA prohibits the discharge of "biological material" into navigable waters of the U.S. without a NPDES permit, the court held that the EPA exceeded its statutory authority by granting the vessel exemption. ${ }^{121}$ Therefore, the court declared that the exemption, 40 C.F.R. $\S 122.3(\mathrm{a})$, be repealed. ${ }^{122}$ In concluding that congressional acquiescence could not overcome a plain reading of the CWA, the court noted that NISA includes a savings clause which is not intended to limit the CWA and that NISA only addresses aquatic nuisance species and does not address other types of pollutants found in ballast water, such as sediment, debris, and rust. ${ }^{123}$

115. $I d$.

116. 467 U.S. 837 (1984).

117. See N.W. Envtl. Advocates, 2005 U.S. Dist. Lexis 5373, at *7 (Chevron set forth a two part test to be used when a court must review an agency interpretation of a statute. Under the first step, the court will determine whether the language of the statute is ambiguous or clear. If the language of the statute is clear, an agency interpretation which is inconsistent with the plain language of the statute will be struck down.).

118. Id. at *29-38.

119. $I d$.

120. $I d$. at $* 35$.

121. Id. at *39.

122. N.W. Envtl. Advocates, 2005 U.S. Dist. Lexis 5373, at *40.

123. $I d$. at $* 35$. 
The resulting effect of the declaratory order in Northwest Environmental Advocates is undetermined because the case is currently awaiting a final remedy order and the EPA will almost certainly appeal the decision to the Court of Appeals for the Ninth Circuit. Therefore, it remains to be seen whether the EPA will ultimately assume jurisdiction over ballast water regulation in the United States.

\section{Weighing the Benefits of Granting the EPA Jurisdiction Over BWM Against the Current Coast Guard Regime}

Three possible benefits will likely be realized if the EPA is given jurisdiction over ballast water management (BWM) under the Clean Water Act (CWA). First, the CWA and the National Pollutant Discharge Elimination System (NPDES) permitting regime are more likely to "drive" BWM technology. Driving technology is particularly important given the claim that current lack of feasible technology is a significant barrier to effective BWM. ${ }^{124}$ Until the appropriate technology is developed, the issue may go unresolved. Second, governmental delays (and inaction) in implementing the necessary BWM standards will likely be reduced through the availability of private citizen suits under the CWA. ${ }^{125}$ Reducing governmental delays is crucial because such delays have surrounded BWM under NANPCA and NISA throughout the last decade. Third, the CWA's "designated uses" and anti-degradation provisions enable the states to protect particular water bodies or areas of water while working within a federal framework. ${ }^{126}$

Several shortcomings are also claimed to arise if the EPA is given jurisdiction over BWM under the CWA. First, because the CWA gives the states primary authority for the NPDES program, it is asserted that a "patchwork" system of regulations would result. ${ }^{127}$ The shipping industry points out that "[a]n EPA rulemaking for ballast water discharges will mark the first time a non-stationary point source that crosses state borders must

124. See Motion and Supporting Memorandum on Selection of Remedy and to Stay Injunction for The Shipping Industry Ballast Water Coalition, supra note 88, at 13.

125. See Cohen \& Foster, supra note 8 , at 840.

126. See Cohen \& Foster, supra note 8, at 843 (stating that "because designated uses in San Francisco Bay are already severely affected as a result of past invasions... it would be difficult to argue that allowing the discharge of additional exotic organisms would be consistent with the CWA's water quality requirements").

127. DRAFt REPORT, supra note 1, at 33-34. 
obtain a permit to discharge effluents under the Clean Water Act." ${ }^{128}$ However, this argument cannot stand because several states have already implemented their own ballast water regulations on top of the current Coast Guard regime. The individual state regulations not only demonstrate the inadequacy of the current federal system but also the futility of arguing that the system is currently "uniform."

Second, it is argued that the NPDES regime will impinge on state efforts to regulate ballast water discharge. ${ }^{129}$ This argument cannot be reconciled with the first argument - that a uniform approach is also desirable.

Third, it is claimed that the NPDES program would subject vessels to overlapping regulatory regimes because NANPCA and NISA already impose BWM requirements. ${ }^{130}$ However, the only requirements currently imposed by law, pursuant to NANPCA and NISA, are the ballast water exchange regulations and reporting requirements. ${ }^{131}$ Such requirements are not in direct conflict with the CWA requirements that dischargers obtain a NPDES permit. ${ }^{132}$

Fourth, it is claimed that lack of effective technologies will hinder the EPA's efforts and that administration and enforcement will be unfeasible. ${ }^{133}$ This argument presents the questions of whether technology driving or forcing is the correct approach and whether administration and enforcement of a permit system can be made feasible. Although technological barriers and administrative and enforcement burdens present themselves as formidable obstacles to success, the benefits which would be inherent in an EPA promulgated program outweigh these rather significant obstacles.

In order to examine the degree to which an EPA promulgated BWM program will improve upon the current regime, the remainder of this Part will discuss in further detail the primary benefits and problems discussed in the preceding two paragraphs. The primary benefits and problems are: a) technology driving/forcing; b) reducing governmental delays and inaction through citizen suits; c) the states' ability to protect particular water bodies while working under a federal framework; and d) special administrative and enforcement problems.

128. Motion and Supporting Memorandum on Selection of Remedy and to Stay Injunction for The Shipping Industry Ballast Water Coalition, supra note 88, at 25.

129. Id. at 35 .

130. $I d$.

131. $I d$.

132. $I d$. (stating that the NISA contains a savings clause which provides that the NISA is not meant to supersede any of the CWA's requirements).

133. DRAFT Report, supra note 1 , at 35. 


\section{A. Technology Driving/Forcing}

Possibly the largest benefit derived from placing the regulation of ballast water under the CWA, and under the jurisdiction of the EPA, is that the EPA has experience in driving technology which the Coast Guard lacks. While the Coast Guard announced in 2004 the beginning of a program to develop ballast water treatment technology, ${ }^{134}$ the CWA is simply better designed to spur technology. Under the CWA, a NPDES permit requires the discharger to meet both technology based treatment requirements, and, where necessary, water quality based requirements. ${ }^{135}$ These two permit requirements have the ability, unlike the Coast Guard's regime, to "spur the regulators and the regulated community" to develop treatment systems that are necessary to effectively reduce the discharge of invasive species into U.S. waters. ${ }^{136}$

In order to create technology based effluent limitations, the CWA divides dischargers into categories of sources. ${ }^{137}$ The CWA then requires all discharges to comply with, at a minimum, best practicable control technology (BPT). ${ }^{138}$ Discharges of toxic and unconventional pollutants must be treated pursuant to the best available technology (BAT) and other types of pollutants must be treated with the best conventional technology (BCT). ${ }^{139}$ These treatment categories are translated into effluent limitations which appear in the NPDES permits as limitations on rates, quantities, and concentrations of pollutants. ${ }^{140}$ In regard to the Clean Water Act's ability to drive treatment technology, the Supreme Court has stated:

The legislative history makes clear why Congress found it so important that the standards be set for "categories" of dischargers, and not for individual dischargers. Congress intended to use the standards as a means to "force" the introduction of more effective pollution control technology .... In establishing [Best Available Technology] levels, it directed EPA to look at "the best performer in an industrial category." By requiring that the standards be set by reference to either the "average of the best" or very "best" technology, the Act seeks to foster technological innovation. ${ }^{141}$

134. See Buck, supra note 4 , at 10 .

135. Natural Res. Def. Council v. EPA, 822 F.2d 104, 109-10 (D.C. Cir. 1987).

136. Plaintiffs' Motion for Permanent Injunctive Relief and Entry of Final Judgment, supra note 74, at 22 .

137. 33 U.S.C. $§ 1314(b)(2005)$.

138. Id. $\S 1311(\mathrm{~b})(1)(\mathrm{a})$.

139. Id. $\$ 1311(\mathrm{~b})(2)$.

140. Id. $\S 1311$; Plaintiffs' Motion for Permanent Injunctive Relief and Entry of Final Judgment, supra note 74 , at $7-8$.

141. Chem. Mfrs. Ass'n v. Natural Res. Def. Council, 470 U.S. 116, 117 (1985) (internal citations 
Biological contaminants found in ballast water should fall under BAT controls as a nonconventional pollutant. The EPA has specifically defined the terms "toxic pollutant" and "conventional pollutant." A toxic pollutant includes disease-causing agents that will cause such effects as death, disease or physical deformities in organisms. ${ }^{142}$ A conventional pollutant includes "pollutants classified as biological oxygen demanding, suspended solids, fecal coliform and $\mathrm{pH} . " 143$ A pollutant that does not fall under either the definition of toxic or conventional falls under the definition of nonconventional. ${ }^{144}$ In the case of ballast water, biological contaminants arguably best fit under the definition of "nonconventional" because they do not fall squarely within either of the other two categories. The EPA should be encouraged to make a determination that biological contaminants are a nonconventional pollutant, subject to BAT requirements, in order to ensure that some degree of technology forcing will be possible.

Where necessary, a NPDES permit also contains restrictions based on a water quality standard (WQS). WQSs are useful where the technology based limitations are not sufficient to meet environmental goals. These standards establish the water quality goals for a water body and are generally established by states. ${ }^{145}$ A WQS consists of two elements: 1) one or more "designated uses" of a waterway; and 2) numeric and narrative "criteria" specifying the nature of the water necessary to meet the designated uses. ${ }^{146}$ Additionally, the CWA's anti-degradation policy prohibits the downgrading of uses for water bodies which are able to meet the numeric or narrative criteria component of the WQS. ${ }^{147}$

While setting WQSs for biological contaminants would be complex, a 2000 report by the California Regional Water Quality Board suggests that it is not impossible. ${ }^{148}$ The report mentions, as one possible approach, a centralized collection and treatment system for ballast water at each port. ${ }^{149}$

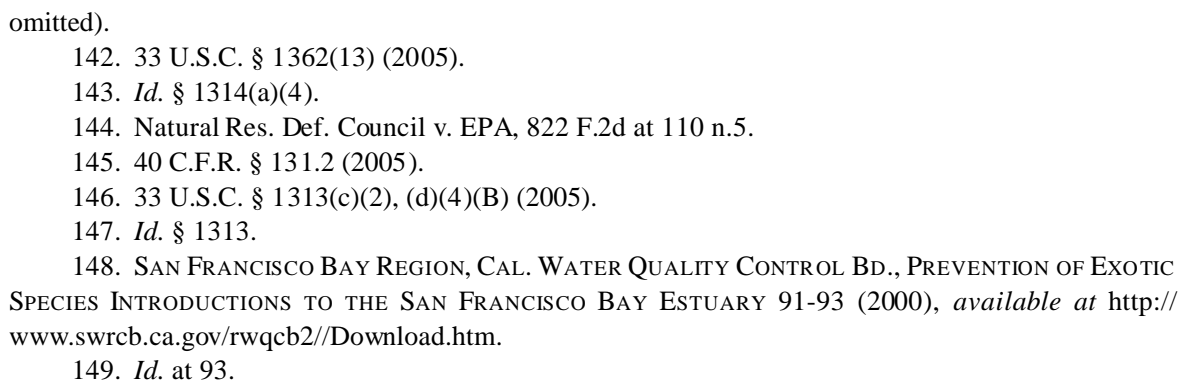


One NPDES permit could be issued for such facilities, and the port would meet its "end-of-pipe" requirements by tailoring requirements for its shipping companies. ${ }^{150}$ The report suggests that these "end-of-pipe" requirements could be "water quality-based (e.g. viable organisms per volume discharged) or treatment-based, as with drinking water requirements in [the United States.]"151 The report also highlights water quality based approaches adopted by other countries, such as Australia, where particularorganisms are identified by their likelihood to cause harm. ${ }^{152}$ This approach includes a determination of the source region for the organism and physiological limits such as temperature and salinity. ${ }^{153}$ Ports are characterized for exotic species throughout Australia and "risk factors are assigned to ships on domestic voyages based on the ports and berths where they take on ballast water."154

In regard to BWM, the argument made by the shipping industry is that open ocean exchange is the best and only practical BWM method currently available. ${ }^{155}$ Industry argues that forcing implementation of treatment technology that is not ready for application will serve as a detriment. The detriment may even include environmental harm. ${ }^{156}$ This argument cannot stand, because the NPDES system has been successful in implementing other "capital intensive" treatment technologies. ${ }^{157}$ For example, NPDES permits have been a successful mechanism for municipal and industrial dischargers in the San Francisco Bay Region to address both toxic pollutants such as selenium in oil refinery discharges and conventional pollutants such as bacteria and biological oxygen demanding substances. ${ }^{158}$

However, absent a regulatory mandate, there will simply be no commercial application for ballast water treatment methods and the "opportunity will be lost to make needed design changes in new vessels that could be in service for decades." ${ }^{159}$ Accordingly, the environmental risk posed by spurring treatment technology is far outweighed by the fact that NPDES permits have resulted in significant decreases in the amount of pollutants

150. $I d$.

151. $I d$.

152. Id. at 95.

153. San Francisco Bay Region, supra note 148, at 95.

154. $I d$.

155. Motion and Supporting Memorandum on Selection of Remedy and to Stay Injunction for The Shipping Industry Ballast Water Coalition, supra note 88, at 18-21.

156. Id. (citing past examples where forcing technology may have lead to environmental harm).

157. San Francisco Bay Region, supra note 148, at 91.

158. $I d$.

159. $I d$. 
discharged into U.S. waters as a result of the combination of both technology based and water quality based effluent limitations. ${ }^{160}$

\section{B. Private Citizen Suits}

Another valuable benefit that will likely arise if the EPA is given jurisdiction over BWM is the reduction of governmental delays in implementing BWM regulation through private citizen suits. Such delays have surrounded government regulation of BWM over the past decade.

In 1996, NISA directed the Coast Guard to create a national ballast water program and issue voluntary guidelines for vessel BWM practices. ${ }^{161}$ Congress intended the guidelines to become mandatory if vessels did not show adequate compliance with the voluntary guidelines. ${ }^{162}$ However, it was not until 2004, eight years after NISA was enacted, that any mandatory federal ballast water regulations were implemented by the Coast Guard. ${ }^{163}$ Such delays may be less likely to occur if ballast water discharge becomes subject to the CWA, primarily because the CWA authorizes private citizen suits.

Under 33 U.S.C. $§ 1365$, a private citizen may sue the EPA for failing to perform any nondiscretionary duty under the CWA. ${ }^{164}$ Therefore, the EPA can be held accountable for failing to take required action in a manner that the Coast Guard simply cannot. For example, the Coast Guard has not been held accountable for exempting ships which arrive at port declaring "no ballast on board" (NBOB) from any type of BWM. ${ }^{165}$ Neither NISA nor the Coast Guard regulations expressly exclude NBOB vessels from performing BWM and it has been maintained that this loophole is due to an improper interpretation and application of both NISA and Coast Guard rules. ${ }^{166}$

In order to close the loophole several states that border on the Great Lakes petitioned the Coast Guard to implement stronger control for discharge of ballast water from vessels that declare NBOB, particularly within the Great

\footnotetext{
at 10 .

160. Plaintiffs' Motion for Permanent Injunctive Relief and Entry of Final Judgment, supra note 74,

161. National Invasive Species Act, Pub. L. No. 104-332, 110 Stat. 4073 (1996).

162. 16 U.S.C. $\$ 4711$ (f)(2)(ii) (2005). 2004).

163. Mandatory Ballast Water Management Program for U.S. Waters, 69 Fed. Reg. 44,952 (July 28,

164. 33 U.S.C. $\$ 1365$ (2005).

165. Brief for the States of New York, Illinois, Michigan, Minnesota, Wisconsin, and the Commonwealth of Pennsylvania on Selection of Remedy and Final Order of Judgment, supra note 61, at 15 .

166. $I d$.
} 
Lakes. These states were concerned about NBOB vessels because ballast tanks, even if unfilled, often contain tons of unpumpable residual ballast water and sediment. ${ }^{167}$ It is claimed that over ninety percent of transoceanic ships entering the Great Lakes evade performing any BWM through the NBOB exception. ${ }^{168}$ A report issued by the U.S. National Oceanic and Atmospheric Administration stated that vessels claiming NBOB present the greatest threat of continuing invasive species introduction in the Great Lakes. ${ }^{169}$

In response to the States' petition, the Coast Guard issued a notice of public meeting and request for comments. ${ }^{170}$ Thereafter, the Coast Guard published a final notice of policy, asking all vessels entering the Great Lakes with ballast tanks, even if unfilled, to either conduct open ocean exchange or to flush their ballast tanks with salt water ("swish-and-spit") in order to maintain high levels of salinity in any residual ballast water. ${ }^{171}$ The Coast Guard has stated that if the voluntary program is ineffective in preventing the introduction of invasive species into the Great Lakes it may consider other alternatives. ${ }^{172}$

The crux of the problem is that by responding to petitions by promulgating only voluntary guidelines the Coast Guard delays implementing effective regulation. Furthermore, public notice and comment procedures lengthen the regulatory process. Comparatively, the EPA may be held accountable in such an instance through a private citizen for failing to perform a nondiscretionary duty. Admittedly, many of the EPA's duties in implementing regulatory details can be considered discretionary. ${ }^{173}$ However, if interested parties seek only review of the Agency's discretionary duties, judicial review under the Administrative Procedure Act will tend to be deferential under the arbitrary and capricious test. ${ }^{174}$ Therefore, even if such

167. Id.

168. $I d$.

169. $I d$.

170. Motion and Supporting Memorandum on Selection of Remedy and to Stay Injunction for The Shipping Industry Ballast Water Coalition, supra note 88, at 9.

171. Id.

172. $I d$.

173. See generally Environmental Litigation (Janet S. Kole et al. eds., 2d ed. 1999) (stating that citizen suits premised on unreasonably delayed agency action have not met with much success in the courts, especially where the deadlines are not clearly set forth).

174. Robert L. Glicksman, The Value of Agency-forcing Citizen Suits to Enforce Nondiscretionary Duties, 10 WidenER L. REv. 353, 388 (2004) (stating that "when agency regulators are perceived as being hostile to the goals of the regulatory schemes they are charged with implementing ... the availability of citizen suits to force the performance of nondiscretionary duties fosters the legitimacy of the regulatory program"). 
citizen suits are few and unsuccessful, their mere availability is a method by which accountability can be placed on the EPA in a manner that has never been available with the Coast Guard.

\section{The States' Ability to Protect Particular Water Bodies under a Federal Framework}

Another benefit to be derived from placing BWM under the CWA and the EPA is that states will have the ability to protect particular water bodies and areas of water while working under a federal framework. The water quality standard (WQS) found in a NPDES permit reflects a state's determination of designated uses for that water body. ${ }^{175}$ Therefore, water bodies with special uses, such as marine estuaries, will have the ability to receive extra protection through an applicable WQS. Protection for high quality water is also provided through the CWA's anti-degradation policy which disallows the downgrading of designated uses for water bodies that are able to meet the numeric or narrative criteria component of the WQS. ${ }^{176}$

Comparatively, the current Coast Guard regulatory regime is inadequate in providing protection for bodies of water with special uses and for high quality bodies of water. Open ocean exchange is the only actual discharge restriction that the Coast Guard has placed on vessels, beyond reporting requirements. ${ }^{177}$ Extra consideration is not given to critical water bodies under the Coast Guard regime and this deficiency may be a reason why some states have felt the need to enact their own BWM regulations.

Not only is the Coast Guard's current open ocean exchange requirement inadequate to curb invasions in especially important water bodies but it also neglects ships engaged in purely coastal trade. ${ }^{178}$ This is because ships engaged in purely coastal trade hug the coastline and never enter the "open" ocean. For example, under the Coast Guard's program a ship leaving Oregon will not have to conduct any BWM procedures before it can discharge ballast water into the waters of California, including marine estuaries. Comparatively, under the CWA, states will have the ability to place restrictions on NPDES discharges into particular water bodies based on the designated use component of the water body's WQS, in conjunction with the CWA's anti-degradation policy.

175. 33 U.S.C. $\S 1313(c)(2)(2005)$.

176. Id. $\S 1313(\mathrm{~d})(4)(\mathrm{B})$.

177. 33 C.F.R. $\$ 151.2041$ (2005).

178. Id. $\S 151.2010$. 


\section{Administration and Enforcement Challenges}

The largest problem presented by giving the EPA jurisdiction over BWM is administrative costs and enforcement challenges. The Coast Guard estimates that 31,000 voyages occur annually from beyond the U.S. Exclusive Economic Zone into the waters of the U.S. ${ }^{179}$ In order to enforce ballast water exchange requirements, salinity tests would have to be conducted on a significant number of these vessels when they reach a U.S. port. If treatment technologies such as biocides are developed, all of the estimated 31,000 voyages would be required to undergo NPDES permitting. Therefore, the EPA could face a possibly insurmountable administrative and enforcement burden.

However, proponents of granting the EPA jurisdiction over BWM argue that administrative burdens can largely be addressed by modeling the permitting system after the NPDES permitting method for industrial discharges into municipal collection systems. ${ }^{180}$ A report by the San Francisco Water Quality Board in 2000 explains how the permitting of industrial discharge into municipal systems has been made feasible:

States and EPA do not have the resources to permit every industry that discharges to a sanitary sewer, so the industrial pretreatment program was established and delegated to cities to implement. The cities remain responsible for the effluent that enters waters of the state, and design their industrial permitting programs to meet their "end-of-pipe" requirements. Some sanitation districts in California regulate over 500 industries under this program. The industrial pretreatment program has reduced industrial pollution of waters of this region by over $90 \%$ on a mass basis since its inception in $1983 .{ }^{181}$

A workable solution to permitting the discharge of billions of gallons of biocide treated ballast water may also be made feasible. Upon the development of treatment technology, facilities at ports can be established for the collection and treatment of ballast water. ${ }^{182}$ Rather than holding each individual ship responsible as a point source, the collection facility can assume such responsibility. One NPDES permit could be issued for each facility, thereby lessening the EPA's administrative and enforcement

179. DRAFT REPORT, supra note 1 , at 7.

180. SAn Francisco BAy Region, supra note 148, at 93.

181. Id.

182. Id. 
burden. ${ }^{183}$ Similar streamlined permits could be issued to ports accepting ships with onboard treatment systems. ${ }^{184}$ Assuming such technology will be developed, the continuing need for open ocean exchange and salinity tests remains questionable. Another possible solution to ease the administrative burden is to issue one permit to a shipping company for a group of ships. ${ }^{185}$

Citizen suits against alleged violators may also possibly assist in enforcement, although several obstacles present themselves. Historically, citizen suits largely focused on alleged failures by the EPA to implement various statutes; however, during the 1980s citizen suits against CWA violators became more numerous. ${ }^{186}$ Citizen suits against CWA violators are inherently more difficult to bring because the plaintiff will usually have difficulty obtaining the necessary data reflecting the violation. ${ }^{187}$ Additionally, the CWA does not permit citizen suits for wholly past violations, but does permit suits based on good faith allegations of intermittent or continuous violations. ${ }^{188}$ Because of the transient nature of vessels, the collection of evidence of ongoing violations will be a large obstacle to a plaintiff wishing to bring a citizen suit against an alleged violator. However, because of the CWA's frequent monitoring requirements and public access to the reports, it would not be impossible for a citizen to bring a suit against an alleged violator. ${ }^{189}$ Additionally, if centralized port facilities are created and held responsible as point sources then the collection of data and the determination of a continuous violation will be made easier.

\section{Conclusion}

Invasive aquatic species present a growing ecological and economic problem that must be dealt with through stricter government regulation and innovative technology. The Coast Guard has had almost ten years to curb the invasive species problem through ballast water management regulation. The only current legal requirements promulgated by the Coast Guard involve open ocean exchange and reporting requirements. For multiple reasons, these procedures are not adequate to effectively manage and curb the invasive

183. Id.

184. Id.

185. SAN FRANCISCO BAy REgION, supra note 148, at 91.

186. EnViRonmental Litigation, supra note 173, at 84-85.

187. Id.

188. Gwaltney of Smithfield, Ltd. v. Chesapeake Bay Found., 484 U.S. 49, 56-57 (1987).

189. See EnVironmental Litigation, supra note 173, at 85. 
species problem. Although solutions to the dilemma are complicated and burdensome, the CWA would serve as a better statutory scheme to implement effective regulation. By placing the regulation of ballast water under the CWA and the EPA, innovative solutions and effective implementation and enforcement are more likely to result. 